\title{
Design of Reminder Information Last Contract (RILC) Applications Using
}

\section{Web-Based Sms Gateway}

\author{
Arip Solehudin ${ }^{1}$ \\ Program Study \\ Teknik Informatika \\ Fakultas Ilmu Komputer, \\ Universitas Singaperbangsa \\ Karawang \\ arip.solehudin@staff.unsika.ac.id
}

\author{
Aldi Angga Putra ${ }^{2}$ \\ Program Study \\ Teknik Informatika \\ Fakultas Ilmu Komputer, \\ Universitas Singaperbangsa \\ Karawang \\ aldi.angga@student.unsika.ac.id kamal.prihandani@unsika.ac.id \\ Kamal Prihandani ${ }^{3}$ \\ Program Study \\ Teknik Informatika \\ Fakultas Ilmu Komputer, \\ Universitas Singaperbangsa \\ Karawang
}

\section{$(\beta)$}

\begin{abstract}
Currently informarsi system is needed by several large companies. To support some data processing, one of them is employee data processing and employee contract data. Given the existing problems in contract data pengelohan often occurs that the check is not maximal so some data left behind and even neglected impact on the increase in salaries of employees who are late due to contracts that are not handled according to schedule. This study aims to create a web-based RIL application using sms gateway for delivery of contract data reminder information. This research uses SDLC method with Extreme Programming model with stages of planning, designing, coding, testing, implementation and evaluation. SMS gateway is a gateway for information dissemination using SMS. With SMS gateway can spread the message of the serial number automatically and quickly which is directly connected with the database of mobile numbers that have been stored. This can be done by RIL applications in sending reminder information messages to the HRD division as well as employees receiving their contract expiration date information. The result of the research is the user can maximize the checking of contract data so that nothing is left behind and give the report that arranged well and clear.
\end{abstract}

Keywords - Contract Data Management, SMS Gateway, Web

Abstrak-Saat ini sistem informarsi dibutuhkan oleh beberapa perusahaan besar. Untuk mendukung beberapa pemrosesan data, salah satunya adalah pengolahan data karyawan dan data kontrak karyawan. Mengingat masalah yang ada dalam pengelohan data kontrak sering terjadi cek yang tidak maksimal sehingga beberapa data tertinggal dan bahkan terabaikan berdampak pada kenaikan gaji karyawan yang terlambat karena kontrak yang tidak ditangani sesuai jadwal. Penelitian ini bertujuan untuk membuat aplikasi RIL berbasis web menggunakan sms gateway untuk pengiriman informasi pengingat data kontrak. Penelitian ini menggunakan metode SDLC dengan model Extreme Programming dengan tahapan perencanaan, perancangan, pengkodean, pengujian, implementasi dan evaluasi. SMS gateway adalah gateway untuk penyebaran informasi menggunakan SMS. Dengan SMS gateway dapat menyebarkan pesan nomor seri secara otomatis dan cepat yang terhubung langsung dengan database nomor ponsel yang telah disimpan. Ini dapat dilakukan oleh aplikasi RIL dalam mengirimkan pesan informasi pengingat ke divisi HRD serta karyawan yang menerima informasi tanggal kedaluwarsa kontrak mereka. Hasil dari penelitian ini adalah pengguna dapat memaksimalkan pemeriksaan data kontrak sehingga tidak ada yang tertinggal dan memberikan laporan yang tertata dengan baik dan jelas.

Kata kunci-Manajemen Data Kontrak, SMS Gateway, Web

\section{INTRODUCTION}

The company has important assets, one of the most important assets of the company in addition to data, namely the managing human resources is the HRD (Human Resources Development) division. One of his duties is to deal with employee contract issues. For that reason, in providing information about employee contracts that will be implemented usually use the Short Message Service (SMS). SMS is one of the most popular cellular services at the moment. For companies and agencies, SMS Gateway is needed because SMS Gateway can provide information facilities related to the activities of the company or agency.

In practice, the processing of employee contract data still uses Microsoft Excel as the main archive material which still experiences several obstacles namely difficulties in checking employee contracts, often even one of the employees who should have finished the contract or the contract will be ignored. With the large number of employee contract data that must be processed and increasingly complex, problems must be addressed and the need for information precisely and quickly. Even the processing of employee contract data does not have an accurate report. Then every time a contract is carried out suddenly without being prepared in advance because it has not been maximized in monitoring employee contract data, which results in fatal salary for employees who should rise when a new contract, but instead becomes left behind even neglected.

Therefore, it is necessary to design a web-based system and contract reminders using an SMS gateway so that it can provide information more quickly and accurately. In addition, monitoring of information, especially employee contract data, is no longer overlooked or left behind in the contract period. This system also provides a reminder message facility via SMS when employee contract data will be exhausted or not yet contracted and will soon be contracted. 
Based on the description above, for this reason, this research builds an application "Design of Reminder Information Last Contract (RIL) application using Webbased SMS Gateway" by using the Extreme Programming (XP) model SDLC methodology including the stages carried out including: planning, designing, coding and Expected testing can provide convenience in the delivery of information needed both management or employees themselves so that the employee contract process according to the contract expiration date.

\section{METHOD}

The methodology used is the SDLC method with the XP model. Which can reduce development costs (Implementation Phase), a semi-formal methodology. Planning Developers must always be ready for changes because changes will always be accepted, or in other words flexible (Maintenance Phase), there are four stages of system development in this XP model, namely: planning, design, coding, and testing.

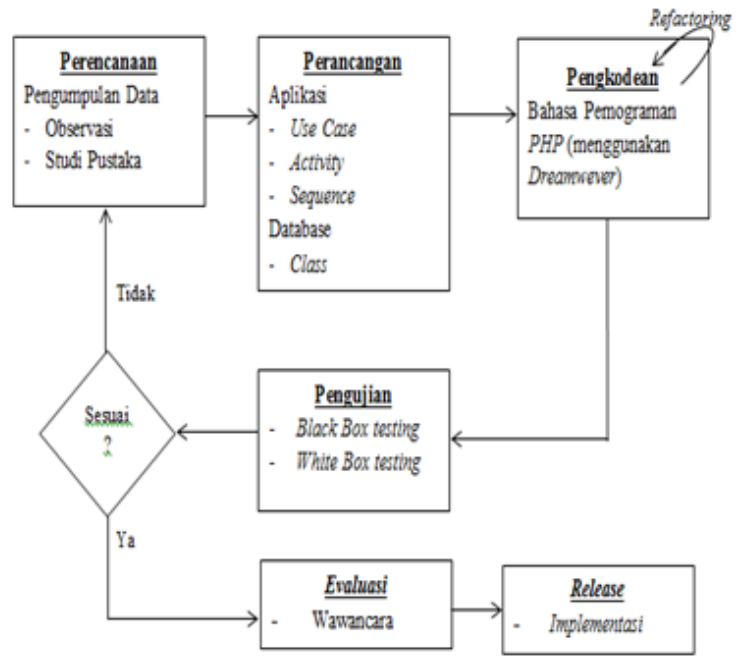

Figure 1 Research Flow

\section{RESULTS AND DISCUSSION}

The results of the research discussed in the previous chapter, will be discussed in this chapter. In this study the design of a Reminder Information Last Contract (RIL) application using a web-based SMS Gateway with the XP model consists of several stages including planning, User Story, design, coding, and testing.

\subsection{Planning}

Planning is done to find out the current problems and to find out the needs needed for the application that will be made in this study.

\subsubsection{User Stories}

Based on data collection by means of interviews obtained problems experienced by potential users as follows,

1. Managing irregular employee contract data.

2. Employee contract data checking is only done by looking at employee contract data in Microsoft Excel to see the expiration date of the employee contract so that sometimes the data is often missed plus there is no reminder information in checking the employee contract data.

3. Inaccurate employee contract data reports. There are always differences in employee contracts, one of which is salary and the expiration date of the employee contract.

4. Don't have an employee contract data processing application as well as an information reminder about employee contract data.

From the problems mentioned above there are several application needs to know clearly and precisely the current problems faced by potential users of this application.

\section{Functional Needs}

Functional requirements analysis is carried out to find out what needs are needed by users of the Reminder Information Last Contract (RIL) application using a web-based SMS Gateway. From the results of the interview in accordance with the user stories that have been made, then obtained some of the needs of users of the Reminder Information Last Contract (RIL) application using web-based SMS Gateway.

a. Assist in declining employee contract data.

b. Helps check and provide employee contract data reminder information.

c. Provide clear and accurate reports.

\section{System User Analysis}

Analysis of system users is done to find the right user for the application to be made. The analysis results obtained from the classification of system users, this application can only be used by the HRD division who knows all employee data, one of which is employee contract data. Whereas the employees themselves only receive a piece of information about the continuation of their contracts, and the director himself only receives a contract report from the system user, HRD.

\subsection{Design}

\subsubsection{Design Modeling}

The design of this application will be built using UML modeling. Where the application architecture design is created using Class Responsibility Collaborator (CRC), use case diagrams, activity diagrams, and sequence diagrams.

\section{Class Responsibility Collaborator (CRC)}

CRC is a collection of standard index cards that have been divided into three parts (classes, responsibilities, collaborators) 


\begin{tabular}{|l|c|}
\hline \multicolumn{2}{|c|}{ Data Kontrak Karyawan } \\
\hline \multicolumn{1}{|c|}{ Responsibilities } & Collaborator \\
\hline $\begin{array}{l}\text { Menambahkan data kontrak } \\
\text { karyawan }\end{array}$ & Divisi HRD \\
\hline Mengedit data kontrak karyawan & Divisi HRD \\
\hline Menghapus data kontrak karyawan & Divisi HRD \\
\hline Menerima Pesan Informasi kontrak & Karyawan \\
\hline
\end{tabular}

Keterangan : Class data karyawan memiliki 4 aksi diantaranya Tambah, edit, hapus sebagai user $H R D$ serta yang menerima pesan informasi kontrak adalah karyawan.

Figure 2 CRC Employee Contract Data

\section{Use Case Diagrams}

The Use Case Diagram describes an interaction between theactor and the application that will be created as shown below:

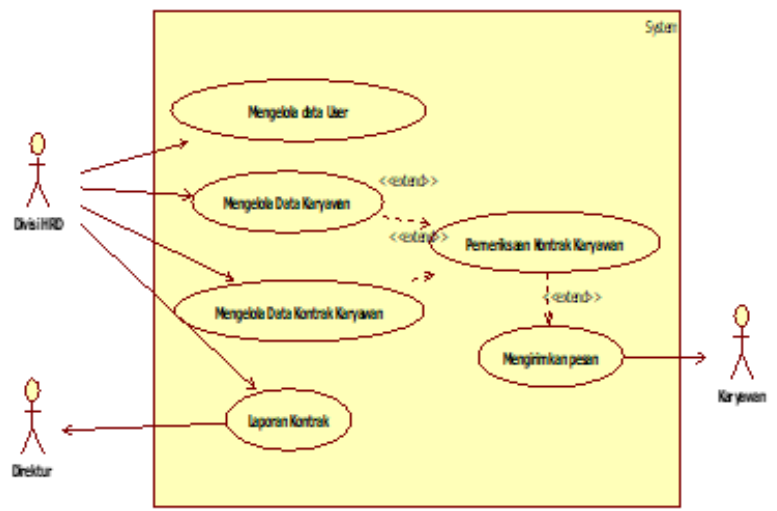

Figure 3. Use Case Diagram of RIL Applications

\section{Activity Diagram}

Activity Diagram explains the activity flow of the system process, with the activity diagram showing more detailed flow of the system running sequentially.

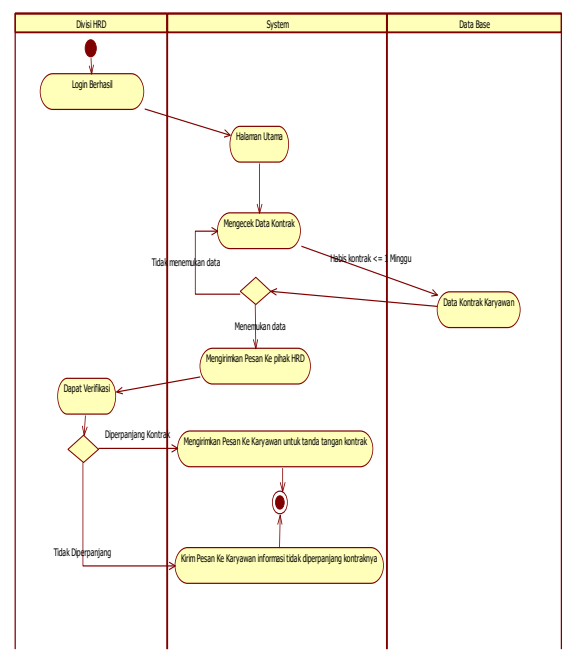

Figure 4 Contract Data Check Activity Diagram
Sequence Diagram illustrates the interaction between objects around the system.

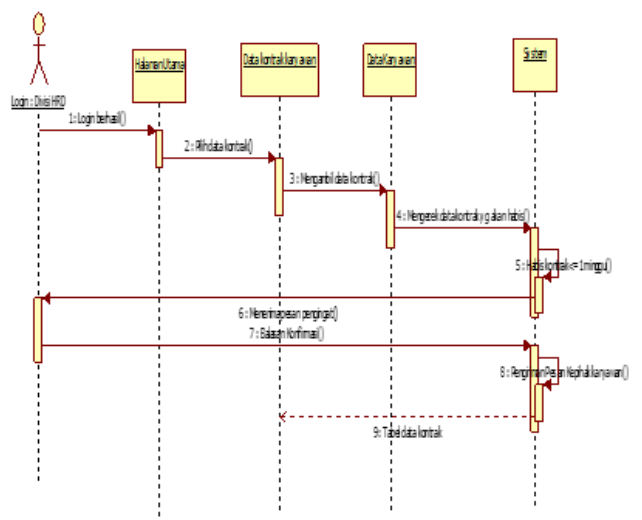

Figure 5. Sequence Diagram Check contract data

\section{Class Diagram}

Class diagrams are used to describe the types of objects in a system, class diagrams also show the properties and operations of a class and the constraints that exist in relation to an object. The following figure 6 is a class diagram presentation from the Rimender Information Last Contract (RIL) application.

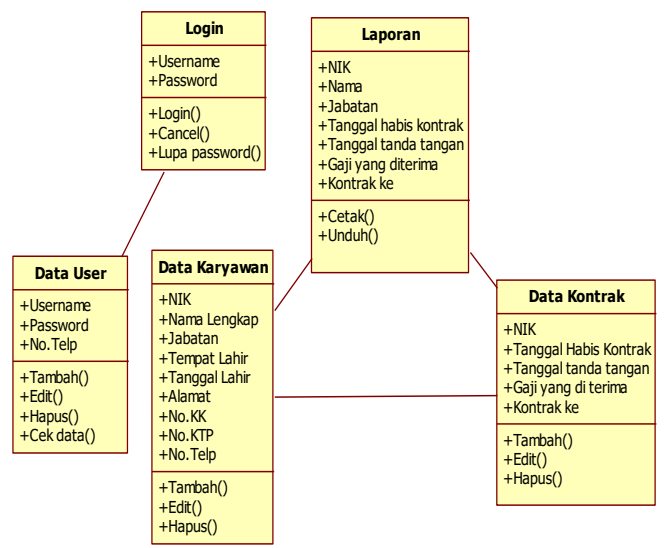

Figure 6. Class Diagram of RIL Applications

\subsubsection{Designing Design}

1. Interface Design

In the interface design a menu structure will be made which is shown below:

a. Employee Contract Data Layout

Next figure 7 is a display of employee contract data from the RIL application.

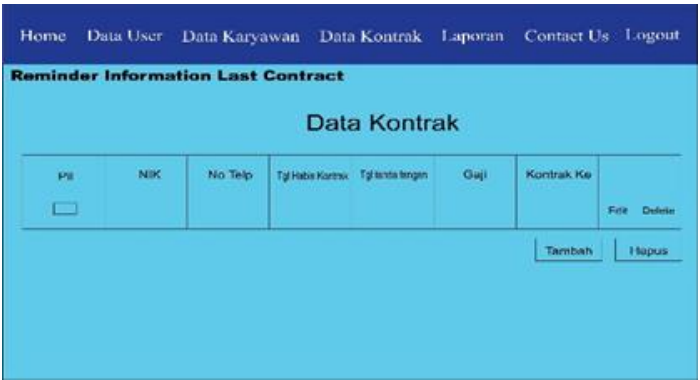

\section{Sequence Diagram}


Figure 7. Employee Contract Data

b. Report Layout

Next figure 8 is a report display from the RIL application.

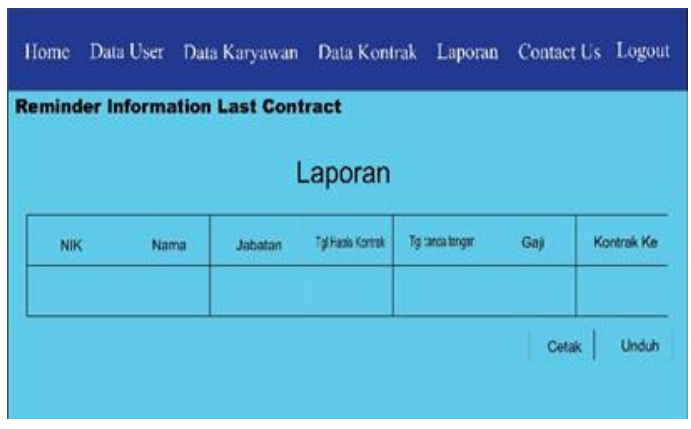

Figure 8. Report

\subsection{Coding}

From the design that has been made then will be translated into a software program (software) whose result is a web-based information last contract (RIL) reminder application created using HTML, CSS, Java Script, PHP and PHPMyAdmin program codes as its database. The following application views for Reminder Information Last Contract (RIL):

\section{a. Display Contract Data Menu}

This display will appear if the user selects the contract data menu in the main menu and in this menu there is an application contract data table from real that we can add, edit or delete and check the contract data that is exhausted. The following picture 9 display contract data.

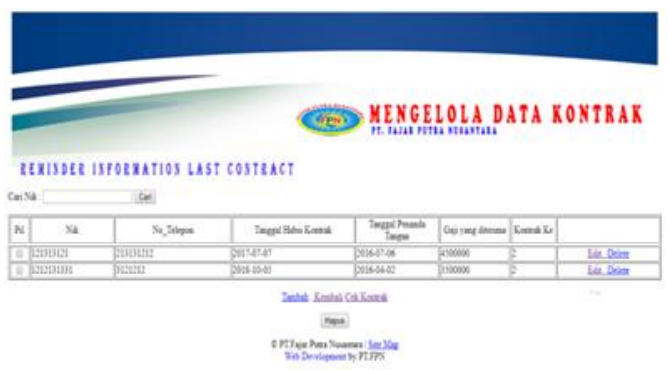

Figure 9. Contract Data Display

\section{b. Report Menu Display}

This display will appear if the user selects the report menu in the main menu and in this menu there is a contract data report table that we can save or print. The following figure 10 display contract reports.

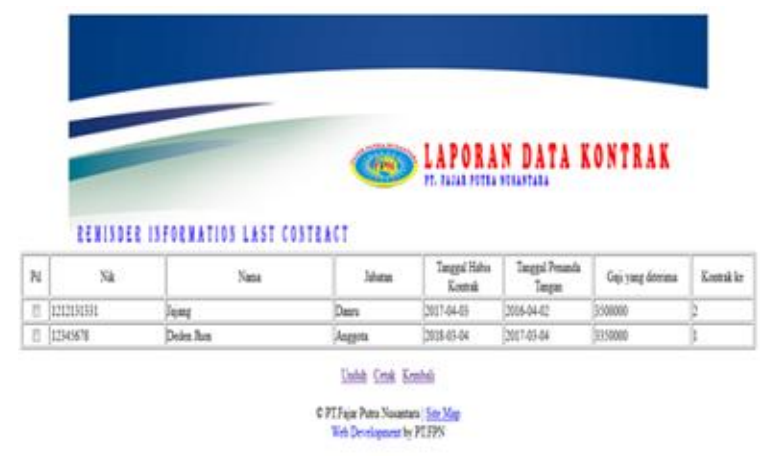

Figure 10. Report Views

\subsection{Testing}

At this stage the user (user) tries an application that has been built according to the user's request. The aim of the user is to evaluate this system in order to see what the user wants as in the user story design stage and identify the problems that occur in the application even though it has been tested before.

Evaluation is done by conducting interviews with the HRD Manager of PT. Fajar Putra Nusantara Karawang:

1. Can the RIL application manage contract data easily?

Answer: Yes, employee data management can be accessed and managed anywhere ...

2. Can the RIL application help with checking contract data?

Answer: Yes, it is very helpful so as to minimize contract data that is left behind. data?

3. Can the RIL application help in remembering contract

Answer: Yes, it is very helpful in remembering good contract data for our HRD division and even the employees concerned.

4. Can the RIL application provide clear and accurate reports?

Answer: Yes, the report is quite clear and accurate.

5 . Does the function of the RIL application fit the needs?

Answer: Yes, the functional needs of the application are sufficient and are as needed.

6. Is the RIL application easy to understand?

Answer: Yes, this application is easy to understand.

\section{CONCLUSION}

Based on the stages of the research that has been done in making this Reminder Information Last Contract (RIL) application, the following conclusions can be drawn:

1. RIL application is applied at PT. Fajar Putra Nusantara to maximize the performance of the HRD division in contract data management.

2. The RIL application utilizes SMS Gateway technology in providing in remittance information for contract data that will run out.

\section{REFERENCES}

[1] Afrina, M., \& Ibrahim, A. (2015). Pengembangan Sistem Informasi SMS Gateway Dalam Meningkatkan Layanan Komunikasi Sekitar Akademika Fakultas Ilmu Komputer Unsri. Jurnal, 855-856.

[2] Edwin B, J., \& Widayati, S. (2013). Jurnal. Aplikasi Pencarian Informasi surat tanda nomor Kendaraan (STNK) berbasis sms gateway, 115 . 
[3] Ahmad, S. B., \& Amir, R. (2020). Sistem Kontrak Kerja Antara Karyawan Dan Perusahaan Perspektif Undang-Undang Ketenagakerjaan Dan Hukum Islam (Studi Kasus di PT Citra Van Titipan Kilat). Shautuna: Jurnal Ilmiyah Mahasiswa Perbandingan Mazhab dan Hukum, 1(2).

[4] Handayani, I., Aini, Q., \& Oktavyanti, Y. (2015). Penggunaan rinfocal sebagai aplikasi pengingat. Jurnal, 3 .

[5] D. Juardi, "Presensi dan Reminder menggunakan QR Code (Studi Kasus: SMA XXX)," SYSTEMATICS, vol. 1. pp. 33-43, 01-Aug2019.

[6] Nurhayati. (2015). Aplikasi sms reminder pada perpustakaan apikesakbid citra medika surakarta. Jurnal, 40.

[7] Adam, A., \& Amri, H. (2019). Prototype Monitoring Arus Dan Tegangan Menggunakan Sms Gateway. Multitek Indonesia, 13(1), 1623.

[8] Nurlaela, F. (2013). Aplikasi Sms Gateway Sebagai Sarana Penunjang Informasi Perpustakaan Pada Sekolah Menengah Pertama Negeri 1 Arjosari. Indonesian Journal on Networking and Security, 20-25.

[9] Solehudin, A., \& Garno, G. (2017). Prototype Api Pada Aplikasi Pembatasan Akses Internet Dengan Pemanfaatan Hak Akses User Profile Hotspot. Jurnal Rekayasa Informasi, 6(2).
[10] Arifin, N. (2019). Analisa Risiko Kontrak Kerja Lumpsum Pada Proyek Gedung K3 Surabaya. axial: jurnal rekayasa dan manajemen konstruksi, 7(1), 25-32.

[11] Fathoni, K., Fariza, A., \& Firmansyah, Y. E. (2019). Rancang Bangun Sistem Informasi Manajemen Kegiatan Penelitian di Politeknik Elektronika Negeri Surabaya. Jurnal Ilmiah Teknologi Informasi Asia, 14(1), 7-18

[12] Solehudin, Arip, Nono Heryana, and Yana Cahyana. "Designing and Building Client-Server Based Student Admission Applications." Buana Information Technology and Computer Sciences (BIT and CS) 1.1 (2020): 16-18.

[13] Hananto, A. L., Solehudin, A., Irawan, A. S. Y., \& Priyatna, B. Analyzing the Kasiki Method Against Vigenere Cipher.

[14] Nuraeni, A., \& Hardianti, S. S. (2019). Aplikasi Penerimaan Karyawan Online Dengan Fitur Informasi Jadwal Tes Dan Hasil Kelulusan. Internal (Information System Journal), 2(1), 1-22.

[15] R. Mayasari, "Sistem Informasi Nilai Mahasiswa Berbasis SMS Gateway menggunakan Trigger pada Database," SYSTEMATICS, vol. 1. pp. 44-57, 01-Aug-2019. 